\section{An evaluation of the burden of Alzheimer patients on family caregivers}

\author{
Avaliação do impacto no cuidador familiar \\ do doente de Alzheimer
}

\author{
${ }^{1}$ Hospital de Clínicas, \\ Universidade Estadual de \\ Londrina, Londrina, Brasil. \\ Correspondence \\ S. R. P. Moraes \\ Ambulatório de Demência, \\ Hospital de Clínicas, \\ Universidade Estadual de \\ Londrina. \\ Rua Caetano Vicentini 100 \\ Londrina, $P R$ \\ 86079-340, Brasil. \\ sandrapinatti@sercomtel. \\ com.br
}

\begin{abstract}
Caregivers are indispensable to persons living with Alzheimer's disease; however, such care involves hard work, and the consequences of this activity on caregivers are often neglected. The objective of this study was to construct a profile for caregivers of Alzheimer patients and to evaluate the burden such care imposes on them. It is a transversal study of 122 caregivers from the metropolitan region of Londrina, Paraná State, Brazil. Socio-demographic data for the caregivers were analyzed, while the Katz scale and Lawton index were used to evaluate the functionality of Alzheimer's patients, and the Burden Interview Scale assessed the burden these patients impose on caregivers. Caregivers are predominantly married, are daughters who have learned to care for the patient on a daily basis, usually with some help, and they do so out of love. The caregiver's age $(p<0.01)$, whether or not the caregiver had help $(p<0.01)$, and the number of hours caring for the patient ( $p=0.01)$ were associated with the impact. Results showed that the burden imposed on caregivers by Alzheimer patients is a heavy one.
\end{abstract}

Caregivers; Alzheimer Disease; Home Nursing
Sandra Renata Pinatti de Moraes 1 Luis Sidônio Teixeira da Silva 1

\section{Introduction}

Research has shown that caring for a patient with mental problems is a lonely and exhausting task $1,2,3$. The redefinition of family roles added to a caregiver's other activities outside the home can lead to emotional, social and financial problems and many diseases. These may get worse if the caregiver is unprepared or as the patient's condition deteriorates, thus imposing a burden 4,5,6,7.

Alzheimer's disease is the most common type of mental illness. It progressively disables individuals, affecting their memory, behavior, relationships, language and other functional activities; demanding the constant presence of a caregiver ${ }^{8}$. In developed countries, caregivers are extremely important, and public and private networks have been created to help to keep the aging person around his or her family 1,9. In Brazil, the responsibility lies exclusively with the patient's family which cannot count on effective public support, while private sector support is expensive and available to very few 9,10 .

Brazilian studies of the burden that Alzheimer disease patients place on caregivers have mostly been carried out in the Southeast region of the country, and they point out co-residence, time spent caring for the patient, and type of relationship with the patient as important factors associated with the burden $6,11,12$. However, such studies deal with mental diseases from different etiologies, with a small number of samples. 
The sample size of this study is larger than any other reported in Brazil for this specific type of mental condition. To evaluate the burden that this type of care poses, very few published instruments have been adapted to the reality of Brazil 13 . Therefore, this study opted for the Burden Interview Scale 14 .

The objective of this study was to construct a profile of the family caregiver and to evaluate the burden this activity imposes on his or her personal life, using the Burden Interview Scale.

\section{Method}

A transversal observational study was carried out at the Mental Health Outpatient Clinic (AHCUEL) of the Londrina State University, Paraná State, Brazil, having been approved by the Research on Human Beings Ethics Committee from the same institution, under reference 066/06.

A list of all patients seen by the clinic from January 2005 to December 2006 (total 330) was provided by the Medical Archives and Statistics Sector of the AHC-UEL. All patients' records were evaluated, and 196 of 330 showed a probable clinical diagnosis for Alzheimer's disease, according to the criteria of the National Institute for Communicative Disorders and Stroke and the Alzheimer's Disease and Related Disorders Association (NINCDS-ADRDA) ${ }^{15}$. The search for caregivers was done by phone and/or mail. Family caregivers were characterized as individuals with greater or total responsibility for supervision and care, and for all activities involving the Alzheimer disease patient 16 .

Family caregivers of both sexes participated in the study, whether they were living with the patient or not, and were required to be over 16 years of age. Caregivers who were excluded included those of deceased patients $(n=16)$, those who lived outside the Londrina metropolitan area $(n=16)$, where they reported that the patient had been institutionalized $(n=4)$, as well as professional and non-professional paid caretakers $(n=16)$. In addition, caregivers that were not registered with the phone company, and those who never returned the contact, which was made twice $(n=13)$, were also excluded.

All in-house interviews were carried out between June 2006 and May 2007, by the researcher, during pre-arranged days and times, when the signature of the free and informed terms of consent was obtained. Socio-demographic data showed how caregivers evaluated the functionality of the patients according to the Daily Life Activities Scale 17 and the Daily Life Instrumental Activities Scale 18, adapted by Scazufca and pub- lished by Almeida 19. Patients who did not need any help were classified as independent whereas those who needed supervision and help to carry out their daily activities were classified as partially dependent. Dependent patients were those classified as totally dependent on a caregiver for performing basic functional needs.

To evaluate the adverse effects of this type of care on the physical, emotional, social and financial life of caregivers, this study used the Burden Interview Scale translated into Portuguese and adapted to the reality of Brazil by Scazufca 14 . The scale is easy to apply and contains 22 questions with five possible answers ranging from "never" to "always". Possible answers were printed on two cards: one numbered from 0 to 4 , to be used with illiterate caregivers, and; another for literate caregivers, showing the graded answers. Global scores were obtained by the sum of all answers, varying from 0 to 88 , so that the higher the score, the greater the burden imposed on the caregiver. All caregivers were instructed to estimate the frequency of the problems occurred during the last month.

Although the scale includes self-explanatory statements, the interviewer read the questions and filled out the questionnaire according to the options selected by the interviewees. Examples taken from the caregivers' experience with the patients were used for clarification in case of doubts regarding any of the questions.

Data were fed into the Epi Info program for Windows 2005 (Centers for Disease Control and Prevention, Atlanta, USA). Discrete variables were given as frequency percentiles and continuous variables as means and standard deviations. The Kolmogorov-Smirnov test verified the presence of a Gaussian distribution in the continuous variables. Student's t tests and the analysis of variance (ANOVA) were used to compare means. Later, data were transferred to the SPSS program version 13.0 (SPSS Inc., Chicago, USA) and a multivariate analysis by the stepwise method was conducted to identify independent variables. The Burden Interview Scale score was used as a dependent variable during the multivariate analysis. In the beginning, the variables selected to be included in the model were those that, during the univariate analysis, showed a $p>0.10$ level of association with the dependent variable. All tests were carried out at the $5 \%$ level of significance. 


\section{Results}

Of the 131 eligible caregivers, nine refused to participate in the study, limiting the sample size to 122 caregivers. The socio-demographic characteristics of the family caregivers are shown in Table 1.

The burden on the caregiver was evaluated using the Burden Interview Scale. Total mean was $37.3 \pm 13.08$ points. The lowest score was 10 and the highest was 66 points. Answers to the Burden Interview Scale questions are presented in Table 2 . The highest levels of burden were observed in women under 60 years of age, with high school and college degrees, who learned to care for the patient on a daily basis, did not get any extra help, and who cared for the patient for more than 10 hours per week (Table 1). A major burden was also observed among caregivers of patients who were dependent on them to carry out instrumental activities such as using the phone $(\mathrm{p}<0.01)$, leaving the house $(\mathrm{p}=0.01)$ going shopping $(\mathrm{p}=0.03)$ and doing chores around the house $(\mathrm{p}=0.04)$ (Table 3). Similarly, a greater burden was verified among caregivers whose patients were dependent on them for basic needs such as bathing $(\mathrm{p}<0.01)$ and getting dressed $(\mathrm{p}=0.03$ ) (Table 4 ).

Variables such as caregiver sex, age, educational level, income level, professional level, as well as type of help (if any), period during which the caregiver cared for the patient, and number of hours spent caring for the patient were included in the mutivariate analysis. Analysis by the stepwise method highlighted the following as significant and independent variables, using an $\mathrm{r}^{2}=0.31, \mathrm{p}<0.01$ model: caregiver age $(\mathrm{p}<0.01)$, the presence of extra help $(p<0.01)$ and number of care hours $(\mathrm{p}=0.01)$.

Socio-demographic characteristics and burden evaluated by the Burden Interview Scale (BI) of 122 family caregivers for Alzheimer's disease patients at the Mental Health Outpatient Clinic of Londrina State University (AHC-UEL). Londrina, Paraná State, Brazil, 2006.

\begin{tabular}{|c|c|c|c|c|}
\hline Characteristics & $n$ * & $\%$ & Mean BI & $\mathrm{p}$-value ** \\
\hline \multicolumn{5}{|l|}{ Gender } \\
\hline Male & 11 & 9.0 & $27.0( \pm 10.8)$ & $<0.01$ \\
\hline Female & 111 & 91.0 & $38.3( \pm 12.8)$ & \\
\hline \multicolumn{5}{|l|}{ Age (years) } \\
\hline$<60$ & 72 & 59.0 & $40.1( \pm 12.5)$ & $<0.01$ \\
\hline$\geq 60$ & 50 & 41.0 & $33.1( \pm 12.8)$ & \\
\hline \multicolumn{5}{|l|}{ Marital status } \\
\hline Married/Partner & 90 & 73.8 & $36.6( \pm 12.4)$ & 0.23 \\
\hline Divorced & 6 & 4.9 & $36.1( \pm 10.4)$ & \\
\hline Single & 24 & 19.7 & $41.2( \pm 15.2)$ & \\
\hline Widower & 2 & 1.6 & $24.5( \pm 12.0)$ & \\
\hline \multicolumn{5}{|l|}{ Educational level } \\
\hline Illiterate & 11 & 9.0 & $34.1( \pm 11.9)$ & 0.04 \\
\hline Primary school & 60 & 49.2 & $34.5( \pm 12.1)$ & \\
\hline High school & 25 & 20.5 & $41.6( \pm 14.1)$ & \\
\hline Higher education/Post & 26 & 21.3 & $40.8( \pm 13.4)$ & \\
\hline \multicolumn{5}{|l|}{ Professional occupation } \\
\hline Homemaker & 47 & 38.5 & $39.0( \pm 13.5)$ & 0.18 \\
\hline Active & 36 & 29.5 & $39.1( \pm 12.4)$ & \\
\hline Inactive & 36 & 29.5 & $33.7( \pm 12.6)$ & \\
\hline Other & 3 & 2.5 & $30.6( \pm 14.6)$ & \\
\hline \multicolumn{5}{|l|}{ Type of relationship } \\
\hline Daughter & 66 & 54.1 & $38.1( \pm 13.0)$ & 0.25 \\
\hline Wife & 32 & 26.2 & $35.4( \pm 11.9)$ & \\
\hline Daughter-in-law & 9 & 7.4 & $43.5( \pm 12.2)$ & \\
\hline Other & 15 & 12.3 & $33.6( \pm 15.2)$ & \\
\hline
\end{tabular}

(continue) 


\begin{tabular}{|c|c|c|c|c|}
\hline Characteristics & $n$ * & $\%$ & Mean BI & $\mathrm{p}$-value ** \\
\hline \multicolumn{5}{|c|}{ Income (as a multiple of the minimum wage) } \\
\hline None & 43 & 35.2 & $39.6( \pm 14.1)$ & 0.09 \\
\hline $1-5$ & 69 & 56.6 & $35.1( \pm 12.7)$ & \\
\hline$>5$ & 10 & 8.2 & $42.4( \pm 14.1)$ & \\
\hline \multicolumn{5}{|l|}{ Religious } \\
\hline Yes & 78 & 63.9 & $36.1( \pm 13.0)$ & 0.18 \\
\hline No & 44 & 36.1 & $39.4( \pm 13.2)$ & \\
\hline \multicolumn{5}{|l|}{ Living together } \\
\hline Yes & 110 & 90.2 & $37.4( \pm 13.4)$ & 0.65 \\
\hline No & 12 & 9.8 & $35.6( \pm 9.8)$ & \\
\hline \multicolumn{5}{|c|}{ Patient contributes towards expenses } \\
\hline Yes & 88 & 72.1 & $38.4( \pm 13.0)$ & 0.12 \\
\hline No & 34 & 27.9 & $34.2( \pm 12.9)$ & \\
\hline \multicolumn{5}{|l|}{ Reasons for caring } \\
\hline Love & 70 & 57.4 & $36.4( \pm 12.9)$ & 0.70 \\
\hline Obligation & 43 & 35.2 & $38.5( \pm 13.6)$ & \\
\hline Other & 9 & 7.4 & $38.1( \pm 12.5)$ & \\
\hline \multicolumn{5}{|c|}{ Learned how to care } \\
\hline Day by day & 76 & 62.3 & $39.2( \pm 13.7)$ & 0.04 \\
\hline Other & 46 & 37.7 & $34.2( \pm 11.5)$ & \\
\hline \multicolumn{5}{|c|}{ Previous experience with this type of caring } \\
\hline Yes & 61 & 50.0 & $36.1( \pm 13.1)$ & 0.32 \\
\hline No & 61 & 50.0 & $38.4( \pm 13.0)$ & \\
\hline \multicolumn{5}{|l|}{ Extra help } \\
\hline Yes & 76 & 62.3 & $34.7( \pm 11.9)$ & $<0.01$ \\
\hline No & 46 & 37.7 & $41.5( \pm 13.8)$ & \\
\hline \multicolumn{5}{|c|}{ Period with the patient (months) } \\
\hline Up to 36 & 58 & 47.6 & $34.6( \pm 12.6)$ & 0.06 \\
\hline $36-96$ & 44 & 36.1 & $40.7( \pm 12.7)$ & \\
\hline More than 96 & 20 & 16.3 & $37.5( \pm 14.0)$ & \\
\hline \multicolumn{5}{|c|}{ Diagnosis period (months) } \\
\hline Up to 12 & 16 & 13.1 & $37.9( \pm 13.6)$ & 0.44 \\
\hline $12-60$ & 87 & 71.4 & $38.3( \pm 13.8)$ & \\
\hline More than 60 & 19 & 15.5 & $31.8( \pm 6.9)$ & \\
\hline \multicolumn{5}{|c|}{ Hours of assistance (hours/week) } \\
\hline Up to 10 & 16 & 13.1 & $30.1( \pm 8.8)$ & 0.02 \\
\hline More than 10 & 106 & 86.9 & $38.3( \pm 13.3)$ & \\
\hline \multicolumn{5}{|c|}{ Leisure time (hours/week) } \\
\hline Up to 5 & 96 & 78.7 & $36.9( \pm 13.8)$ & 0.49 \\
\hline $5-10$ & 7 & 5.8 & $34.2( \pm 6.2)$ & \\
\hline More than 10 & 19 & 15.5 & $40.2( \pm 14.8)$ & \\
\hline
\end{tabular}

* Number of participants;

** The statistical analysis was carried out by the $t$ Student test to compare means between the two categories and by the ANOVA where 3 or more categories were compared. 
Zarit Burden Interview Scale applied to 122 family caregivers of Alzheimer's disease patients at the Mental Health Outpatient Clinic of Londrina State University (AHC-UEL). Londrina, Paraná State, Brazil, 2006.

\begin{tabular}{|c|c|c|c|c|c|}
\hline Elements of the Burden Interview Scale & $\begin{array}{l}\text { Never } \\
\text { n (\%) }\end{array}$ & $\begin{array}{l}\text { Rarely } \\
\text { n (\%) }\end{array}$ & $\begin{array}{l}\text { Sometimes } \\
\text { n (\%) }\end{array}$ & $\begin{array}{l}\text { Frequently } \\
\text { n (\%) }\end{array}$ & $\begin{array}{l}\text { Always } \\
\text { n (\%) }\end{array}$ \\
\hline $\begin{array}{l}\text { Do you feel that your relative asks for more help than } \\
\text { he/she needs? }\end{array}$ & $46(37.7)$ & $20(16.4)$ & $22(18.0)$ & $14(11.5)$ & $20(16.4)$ \\
\hline $\begin{array}{l}\text { Do you feel that because of the time you spend with } \\
\text { your relative that you don't have enough time for } \\
\text { yourself? }\end{array}$ & $25(20.5)$ & $28(23.0)$ & $35(28.7)$ & $12(9.8)$ & $22(18.0)$ \\
\hline $\begin{array}{l}\text { Do you feel stressed between caring for your relative } \\
\text { and trying to meet other responsibilities for your } \\
\text { family or work? }\end{array}$ & $24(19.7)$ & $11(9.0)$ & $42(34.4)$ & $19(15.6)$ & $26(21.3)$ \\
\hline $\begin{array}{l}\text { Do you feel embarrassed about your relative's } \\
\text { behavior? }\end{array}$ & $81(66.4)$ & $8(6.6)$ & $30(24.6)$ & $2(1.6)$ & $1(0.8)$ \\
\hline Do you feel angry when you are around your relative? & $49(40.2)$ & $17(13.9)$ & $39(32.0)$ & $10(8.2)$ & $7(5.7)$ \\
\hline $\begin{array}{l}\text { Do you feel that your relative currently affects } \\
\text { your relationships with other family members } \\
\text { or friends in a negative way? }\end{array}$ & $63(51.6)$ & $10(8.2)$ & $25(20.5)$ & $15(12.3)$ & $9(7.4)$ \\
\hline Are you afraid what the future holds for your relative? & $12(9.8)$ & $7(5.7)$ & $27(22.1)$ & $29(23.8)$ & $47(38.5)$ \\
\hline Do you feel your relative is dependent on you? & - & $2(1.6)$ & $8(6.6)$ & $20(16.4)$ & $92(75.4)$ \\
\hline Do you feel strained when you are around your relative? & $48(39.3)$ & $13(10.7)$ & $38(31.1)$ & $10(8.2)$ & $13(10.7)$ \\
\hline $\begin{array}{l}\text { Do you feel your health has suffered because } \\
\text { of your involvement with your relative? }\end{array}$ & $38(31.1)$ & $12(9.8)$ & $37(30.3)$ & $23(18.9)$ & $12(9.8)$ \\
\hline $\begin{array}{l}\text { Do you feel that you don't have as much privacy as } \\
\text { you would like because of your relative? }\end{array}$ & $46(37.7)$ & $10(8.2)$ & $35(28.7)$ & $16(13.1)$ & $15(12.3)$ \\
\hline $\begin{array}{l}\text { Do you feel that your social life has suffered because } \\
\text { you are caring for your relative? }\end{array}$ & $30(24.6)$ & $16(13.1)$ & $31(25.4)$ & $19(15.6)$ & $26(21.3)$ \\
\hline $\begin{array}{l}\text { Do you feel uncomfortable about having friends } \\
\text { over because of your relative? }\end{array}$ & $92(75.4)$ & $8(6.6)$ & $10(8.2)$ & $7(5.7)$ & $5(4.1)$ \\
\hline $\begin{array}{l}\text { Do you feel that your relative seems to expect you } \\
\text { to take care of him/her as if you were the only } \\
\text { one he/she could depend on? }\end{array}$ & $15(12.3)$ & $5(4.1)$ & $18(14.8)$ & $20(16.4)$ & $64(52.5)$ \\
\hline $\begin{array}{l}\text { Do you feel that you don't have enough money } \\
\text { to take care of your relative in addition to } \\
\text { the rest of your expenses? }\end{array}$ & $49(40.2)$ & $13(10.7)$ & $27(22.1)$ & $13(10.7)$ & $20(16.4)$ \\
\hline $\begin{array}{l}\text { Do you feel that you will be unable to take care of } \\
\text { your relative for much longer? }\end{array}$ & $57(46.7)$ & $15(12.3)$ & $33(27.0)$ & $10(8.2)$ & $07(5.7)$ \\
\hline $\begin{array}{l}\text { Do you feel you have lost control of your life since } \\
\text { your relative's illness? }\end{array}$ & $35(28.7)$ & $17(13.9)$ & $35(28.7)$ & $15(12.3)$ & $20(16.4)$ \\
\hline $\begin{array}{l}\text { Do you wish you could leave the care of your relative } \\
\text { to someone else? }\end{array}$ & $69(56.6)$ & $8(6.6)$ & $31(25.4)$ & $2(1.6)$ & $12(9.8)$ \\
\hline $\begin{array}{l}\text { Do you feel uncertain about what to do about } \\
\text { your relative? }\end{array}$ & $43(35.2)$ & $16(13.1)$ & $46(37.7)$ & $8(6.6)$ & $9(7.4)$ \\
\hline $\begin{array}{l}\text { Do you feel you should be doing more for } \\
\text { your relative? }\end{array}$ & $37(30.3)$ & $10(8.2)$ & $27(22.1)$ & $16(13.1)$ & $32(26.2)$ \\
\hline $\begin{array}{l}\text { Do you feel you could do a better job in caring } \\
\text { for your relative? }\end{array}$ & 35 (28.7) & $19(15.6)$ & $28(23.0)$ & $12(9.8)$ & $28(23.0)$ \\
\hline $\begin{array}{l}\text { Overall. How burdened do you feel in caring for } \\
\text { your relative? * }\end{array}$ & $16(13.1)$ & $44(36.1)$ & $22(18.0)$ & $35(28.7)$ & $5(4.1)$ \\
\hline
\end{tabular}

* In this question the answers are: $0=$ nothing, $1=$ a little, $2=$ moderately, $3=$ a lot, and 4 = extremely. 
Alzheimer's disease patients' dependence during daily instrumental activities and its burden on 122 family caregivers seen at the Mental Health Outpatient Clinic of Londrina State University (AHC-UEL). Londrina, Paraná State, Brazil, 2006.

\begin{tabular}{|c|c|c|c|c|c|c|c|c|c|c|}
\hline \multirow[t]{2}{*}{ Daily instrumental activities } & \multicolumn{3}{|c|}{ Independent } & \multicolumn{3}{|c|}{ Help } & \multicolumn{3}{|c|}{ Dependent } & \multirow[t]{2}{*}{ p-value * } \\
\hline & $\mathbf{n}$ & $\%$ & Mean BI & $\mathrm{n}$ & $\%$ & Mean BI & $\mathbf{n}$ & $\%$ & Mean BI & \\
\hline Telephone ** & 14 & 12.6 & 26.3 & 13 & 11.7 & 36.0 & 84 & 75.7 & 39.7 & $<0.01$ \\
\hline Locomotion outside the house & 14 & 11.5 & 32.1 & 41 & 33.6 & 33.9 & 67 & 54.9 & 40.4 & 0.01 \\
\hline Shopping & 14 & 11.5 & 28.9 & 14 & 11.5 & 36.2 & 94 & 77.0 & 38.6 & 0.03 \\
\hline Meals & 14 & 11.5 & 30.7 & 16 & 13.1 & 34.5 & 92 & 75.4 & 38.7 & 0.07 \\
\hline Household chores & 15 & 12.3 & 32.6 & 25 & 20.5 & 33.3 & 82 & 67.2 & 39.3 & 0.04 \\
\hline Medication & 9 & 7.4 & 33.3 & 22 & 18.0 & 32.9 & 91 & 74.6 & 38.7 & 0.11 \\
\hline Money & 13 & 10.7 & 30.8 & 21 & 17.2 & 38.3 & 88 & 72.1 & 38.0 & 0.17 \\
\hline
\end{tabular}

BI: Burden Interview Scale.

* The probability described refers to the statistical analysis carried out with ANOVA between the burden assessed by the Burden Interview Scale and the respective daily instrumental activity;

** 11 caregivers were excluded from this variable since their patients never used the phone.

Table 4

Alzheimer's disease patients' dependence in carrying out daily basic activities and its burden on family caregivers seen at the Mental Health Outpatient Clinic of Londrina State University (AHC-UEL). Londrina, Paraná State, Brazil, 2006.

\begin{tabular}{|c|c|c|c|c|c|c|c|c|c|c|}
\hline \multirow[t]{2}{*}{ Daily basic activities } & \multicolumn{3}{|c|}{ Independent } & \multicolumn{3}{|c|}{ Help } & \multicolumn{3}{|c|}{ Dependent } & \multirow[t]{2}{*}{ p-value * } \\
\hline & $\mathrm{n}$ & $\%$ & Mean BI & $\mathrm{n}$ & $\%$ & Mean BI & $\mathbf{n}$ & $\%$ & Mean BI & \\
\hline Bathing & 55 & 45.1 & 33.2 & 24 & 19.7 & 41.7 & 43 & 35.2 & 40.0 & $<0.01$ \\
\hline Dressing & 54 & 44.3 & 33.8 & 10 & 8.2 & 39.8 & 58 & 47.5 & 40.0 & 0.03 \\
\hline Going to the bathroom & 85 & 69.7 & 36.0 & 17 & 13.9 & 37.2 & 20 & 16.4 & 42.4 & 0.15 \\
\hline Moving & 103 & 84.4 & 36.9 & 11 & 9.0 & 36.4 & 8 & 6.6 & 43.0 & 0.45 \\
\hline Urinary continence & 69 & 56.5 & 35.7 & 28 & 23.0 & 38.7 & 25 & 20.5 & 40.0 & 0.30 \\
\hline Meals & 68 & 55.7 & 35.5 & 37 & 30.3 & 39.5 & 17 & 14.0 & 39.5 & 0.25 \\
\hline
\end{tabular}

BI: Burden Interview Scale.

* The probability described refers to the statistical analysis carried out with ANOVA between the burden assessed by the Burden Interview Scale and the respective daily basic activity.

\section{Discussion}

This study is pioneering in its attempts to construct a profile and to evaluate the burden that Alzheimer disease patients impose on caregivers. It uses patients from AHC-UEL and an expressive sample of 122 caregivers, a number higher than any other found in studies published in Brazil 3,6. There is no universal benchmark established which allows for the classification of burden measured by the Burden Interview Scale as low or high; however, by comparing the burden index found in this study with other Brazilian studies, we observed that the scores were similar to those found for Porto Alegre, Rio Grande do Sul State 3 and higher than those found for the city of São Paulo 6,11,12. Compared to international studies, the burden described in this study is greater than those reported in China and India, showing that in cultures where people are devoted to their elderly people and see caring for them as a family (children or spouse) obligation, caregivers have difficulty admitting any suffering, a characteristic that was more readily apparent among Latin caregivers $2,7,10$.

Some characteristics of caregivers found in this study such as female, age below 60 , and being the patient's relative were the variables most commonly found in many international studies $1,13,16$. For cultural reasons, societies pass on to 
women the caregiver role, and single daughters are more predisposed to care for the patient due to their emotional and/or financial dependence, for co-residing with the patient and for not yet having started their own family 7,16,20. However, due to financial needs and the search for equal rights between the sexes, this paradigm is shifting and women are participating in the job market, accumulating skills. Consequently, they are subject to emotional, physical and social problems which can intensify the burden score 21 . Results have also shown that female caregivers are subject to a greater burden than their male counterparts 6,22. Although, males also act as caregivers, the care they provide to Alzheimer's disease patients is limited to their instrumental needs $6,10,16,22$. Data from this research was insufficient to evaluate the burden on this subgroup due to the small sample size.

Some methodological limitations such as the use of a convenience sample made up of caregivers of patients from a tertiary service do not allow generalizations to other types of chronic-degenerative diseases. Other possible interferences came from estimating the patient's functional and cognitive needs based only on the caregiver's point of view and from adopting instruments developed originally to be self-applicable but which, in this study, were conducted by the interviewer. The instrument stresses subjective data which can be underestimated or overestimated in different populations, thus jeopardizing any comparison among published studies. In addition, patients were not categorized according to their Alzheimer disease stage, and the difference of the burden on caregivers in different phases of the patients' disease were not evaluated. The non-categorization of the deficit levels of patients with Alzheimer disease also makes comparison among studies difficult 3,6,11, since it is not clear whether caregivers were involved with patients with similar levels of the disease.

The incomes of elderly person and of the caregiver were not considered important factors in this study; however, Printz-Feddersen 23 believes that this variable affects burden, since a higher income could provide the caregiver with additional help to ease his or her burden. An outside job to complement family income prevents the social isolation of the caregiver but reduces the time spent with the patient as the disease intensifies and his dependence on the caregiver increases. This task is usually taken over by other family members and indirectly by maids. A study of Brazilian and Japanese family caregivers in the Southeast region of Brazil showed that the help of maids is effective and gives the caregiver more time for his or her other family businesses, spending more time with their family and on personal and professional activities 10 .

In this study, the level of education of the interviewees was up to 8 years, a finding similar to those reported by other national publications $3,6,11$. However, higher levels of education had a significant positive impact on the caregiver. Other studies do not show this association, probably due to the lack of standardized data collection instruments and categorization of analyzed variables, which could have prevented comparison between studies, thus making the generalization of findings difficult 6,12,13.

Affection contributed the most to the exercise of caring analyzed in this study. According to the literature, the caregiver carries out his or her role out of love, gratitude, and marital or legal obligations 10,21. Among the "time spent with the patient" variables, only the "weekly assistance" affected burden, which was greater according to the number of hours spent caring for the patient, a finding corroborated by the literature 6,12 . The influence of time on the caregiver's burden is controversial since this variable is seldom studied, and can be registered without the association of this variable with burden being evaluated 13. Garcia 24, studying family life and the Alzheimer disease patient, verified that a long period of caring for the patient can work as a protection against burden. Conversely, data from this research show the increasing dependence of the patient to be a strong source of burden on the caregiver, a finding that is supported by Garrido \& Menezes 6 .

As for the daily activities and the burden they impose on the caregiver, previous research findings are inconsistent 19,25,26. In this study, instrumental and basic daily activities which had a greater influence on burden were: using the telephone, locomotion, going shopping, carrying out household chores, bathing and getting dressed. The sample size may have been too small to detect the statistical significance of other variables.

Results showed that family caregivers are generally women, 29 to 88 years of age, with 8 years of schooling, who live with the patient and care for him/her with love. The burden that Alzheimer's disease patients place on family caregivers evaluated at AHC-UEL was great and independently associated with gender, the presence of extra help and the number of hours spent caring for the patient.

The provision of structured assistance to caregivers is still lacking in Brazil, and for this reason the attention given to family caregivers needs to be reevaluated by health officials. Support to caregivers through meetings, lectures and home visits with the help of a multiprofessional team 
will contribute to the planning and implementation of activities for the patient, encouraging caregivers to accept their limitations and to ask for help, promoting the sharing of experiences among them and mutual growth. These strategies can reinforce family and community bonds, reducing the great burden imposed on caregiv-

\section{Resumo}

O cuidador é indispensável ao paciente com doença de Alzheimer, no entanto cuidar é uma tarefa árdua, e as conseqüências dessa atividade em quem cuida são negligenciadas. Estudo transversal realizado na região metropolitana do Município de Londrina, Paraná, Brasil, tem por objetivo caracterizar o perfil e avaliar o impacto da ação sobre 122 cuidadores principais de pacientes com doença de Alzheimer. A escala de Katz e o indice de Lawton foram utilizadas para avaliar a funcionalidade dos pacientes com doença de Alzheimer, e a Burden Interview Scale, para avaliar o impacto no cuidador. Caracterizaram-se seus dados sócio-demográficos. Os cuidadores foram predominantemente filhas, casadas, que aprenderam o cuidado no dia-a-dia, contavam com auxílio e exerciam a função por afeto. Associaram-se ao impacto de forma independente: idade do cuidador $(p<0,01)$, contar com auxílio $(p<0,01)$ e número de horas de cuidado $(p=$ $0,01)$. Os cuidadores estudados apresentaram impacto elevado.

Cuidadores;Doença de Alzheimer;Assistência Domiciliar ers. Longitudinal research that investigates the relevance of the variables studied here will provide information on the caregiver burden in different regions around the country, on areas that need intervention and on the best strategy to be adopted, since the well being of the caregiver is essential for good quality care.

\section{Contributors}

S. R. P. Moraes was responsible for the bibliographic review, data collection, data processing and revision, interpretation of results and the writing of the article. L. S. T. Silva helped with the selection of the instruments, methodology, development of the article and revision of the final draft.

\section{Acknowledgments}

To José Carlos Dalmas, $\mathrm{PhD}$ for his statistical contributions and Rose Meire de Albuquerque Pontes, PhD for her critical revision of the text. 


\section{References}

1. Schneider J, Murray J, Banerjee S, Mann A. EUROCARE: a cross-national study co-resident spouse carers for people with Alzheimer's disease: I - Factors associated with carer burden. Int J Geriatr Psychiatry 1999; 14:651-61.

2. Prince M. Care arrangements for people with dementia in developing countries. Int J Geriatr Psychiatry 2004; 19:170-7.

3. Luzardo AR, Gorini MIPC, Silva APSS. Características de idosos com doença de Alzheimer e seus cuidadores: uma série de casos em um serviço de neurogeriatria. Texto \& Contexto Enferm 2006; 15:587-94.

4. Zarit SH, Reever KE, Bach-Peterson J. Relatives of the impaired elderly: correlates of feelings of burden. Gerontologist 1980; 20:649-55.

5. Neri AL, Carvalho VAML. O bem-estar do cuidador: aspectos psicossociais. In: Freitas EV, Py L, Neri AL, Cançado FAX, Gorzoni ML, Rocha SM, organizadores. Tratado de geriatria e gerontologia. Rio de Janeiro: Editora Guanabara Koogan; 2002. p. 778-9.

6. Garrido R, Menezes PR. Impacto em cuidadores de idosos com demência atendidos em um serviço psicogeriátrico. Rev Saúde Pública 2004; 38: 835-41.

7. Giacomin KC, Uchoa E, Lima-Costa MFF. Projeto Bambuí: a experiência do cuidado domiciliário por esposas de idosos dependentes. Cad Saúde Pública 2005; 21:1509-18.

8. Machado JCB. Doença de Alzheimer. In: Freitas EV, Py L, Neri AL, Cançado FAX, Gorzoni ML, Rocha SM, organizadores. Tratado de geriatria e gerontologia. Rio de Janeiro: Editora Guanabara Koogan; 2002. p. 133-47.

9. Karsch UM. Idosos dependentes: famílias e cuidadores. Cad Saúde Pública 2003; 19:861-6.

10. Santos SMA. O cuidador familiar de idosos com demências: um estudo qualitativo em famílias de origem nipo-brasileira e brasileira [Tese de Doutorado]. Campinas: Faculdade de Educação, Universidade Estadual de Campinas; 2003.

11. Amendola F. Qualidade de vida de cuidadores de pacientes com perdas funcionais e dependência atendidos em domicílio pelo Programa Saúde da Família do município de São Paulo [Dissertação de Mestrado]. São Paulo: Universidade de São Paulo; 2007.

12. Cassis SVA, Karnakis T, Moraes TA, Curiati JAE, Quadrante ACR, Magaldi RM. Correlação entre estresse do cuidador e as características clínicas do paciente portador de demência. Rev Assoc Med Bras 2007; 53:497-501.

13. Garrido R, Almeida OP. Distúrbios de comportamento em pacientes com demência: impacto sobre a vida do cuidador. Arq Neuropsiquiatr 1999; 57:427-34
14. Scazufca M. Brazilian version of the Burden Interview Scale for the assessment of burden of care in carers of people with mental illnesses. Rev Bras Psiquiatr 2002; 24:12-7.

15. McKhann G, Drachman D, Folstein M, Katzman R, Price D, Stadlan EM. Clinical diagnosis of $\mathrm{Al}$ zheimer's disease: report of NINCDS-ADRDA Work Group under the auspices of Department of Heath and Human Services Task Force on Alzheimer's Disease. Neurology 1984; 23:939-44.

16. Stone R, Cafferata GL, Sangl J. Caregivers of the frail elderly: a national profile. Gerontologist 1987; 27:616-26.

17. Katz S, Ford AB, Moskowitz RW, Jackson BA, Jaffe MW. Studies of illness in the aged. The index of ADL: a standardized measure of biological and psychosocial function. JAMA 1963; 185:914-9.

18. Lawton MP, Brody E. Assessment of older people: self-maintaining and instrumental activities of daily living. Gerontologist 1969; 9:179-86.

19. Almeida OP. Instrumentos para avaliação em pacientes com demência. In: Gorenstein C, Andrade LHSG, Zuardi AW, organizadores. Escalas de avaliação clínica em psiquiatria e psicofarmacologia. São Paulo: Lemos Editorial; 2000. p. 331-43.

20. Nakatani AYK, Souto CCS, Paulette LM, Melo TS, Souza MM. Perfil dos cuidadores formais de idosos com déficit de autocuidado atendidos pelo Programa de Saúde da Família. Revista Eletrônica de Enfermagem 2003; 5(1). http://www.fen.ufg.br/ revista.

21. Vilela ABA, Meira EC, Souza AS, Souza DM, Cardoso IS, Sena ELS, et al. Perfil do familiar cuidador de idoso doente no contexto de Jequié-BA. Rev Bras Geriatr Gerontol 2006; 9:55-69.

22. Chan TSF, Lam LCW, Chiu HFK. Validation of the Chinese version of the Zarit Burden Interview. Hong Kong Journal of Psychiatry 2005; 15:9-13.

23. Printz-Feddersen V. Group process effect on caregiver burden. J Neurosci Nurs 1990; 22:164-8.

24. Garcia FG. Convivência familiar com o idoso acometido pela doença de Alzheimer: estudo de caso [Dissertação de Mestrado]. Vitória: Universidade Federal do Espírito Santo; 2006.

25. Donaldson C, Tarrier N, Burns ACD, Tarrier N, Burns A. The impact of the symptoms of dementia on caregivers. Br J Psychiatry 1997; 170:62-8.

26. Arai Y, Yashio M. Burden felt by family caring for the elderly members needing care in southern Japan. Aging Ment Health 1999; 3:158-64.

Submitted on 12/Aug/2008

Final version resubmitted on $08 / \mathrm{Jan} / 2009$

Approved on 13/Feb/2009 